\title{
EFEK PENAMBAHAN ALUMINIUM TERHADAP KETAHANAN OKSIDASI TEMPERATUR TINGGI PADUAN LOGAM FERROSILICON-MAGNESIUM
}

\author{
Lusita $^{1, \text { a) }}$, Bambang Hermanto ${ }^{2, \text { b) }}$, Anggara Budi Susila ${ }^{1, c)}$, Toto Sudiro ${ }^{2, d)}$ \\ ${ }^{1}$ Program Studi Fisika, Fakultas Matematika dan Ilmu Pengetahuan Alam, Universitas Negeri Jakarta, \\ Rawamangun, Jakarta Timur, DKI Jakarta, Indonesia, 13220 \\ ${ }^{2}$ Pusat Penelitian Fisika, Lembaga Ilmu Pengetahuan Indonesia (LIPI), Kompleks Puspiptek Gedung 440-442, \\ Serpong, Tangerang Selatan, Banten, Indonesia, 15314
}

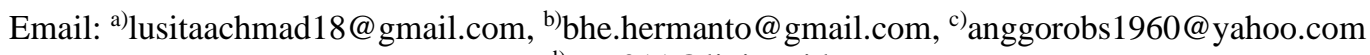
d)toto011@lipi.go.id

\begin{abstract}
Abstrak
Paduan Fe-Si-Mg-Al dengan variasi komposisi ferrosilicon-magnesium dan Al yaitu [A] 100(Fe-Si$\mathrm{Mg}$ ); [B] 97,79(Fe-Si-Mg)-2,21Al; [C] 94,79(Fe-Si-Mg)-5,27Al; dan [D] 89,16(Fe-Si-Mg)-10,84Al telah disintesa menggunakan teknik metalurgi serbuk. Struktur dan ketahanan oksidasi dari paduan logam Fe-Si-Mg-Al dengan atau tanpa penambahan Al dipelajari menggunakan X-ray Diffractometer (XRD) untuk mengetahui fasa yang terbentuk, Scanning Electron Microscope-Energy Dispersive X-ray Spectrometer (SEM-EDS) untuk menganalisa morfologi dan sebaran elemen serta komposisi paduan, dan uji oksidasi dilakukan di dalam muffle furnace pada temperatur $800 \mathrm{oC}$ untuk mengevaluasi ketahanan oksidasi paduan logam pada suhu tinggi. Hasil XRD dan SEM-EDS menunjukkan bahwa paduan logam $\mathrm{Fe}-\mathrm{Si}-\mathrm{Mg}$-Al telah berhasil disintesa. Sebelum oksidasi, paduan ini tersusun atas fasa $\mathrm{Si}$, $\mathrm{FeSi}, \alpha$-FeSi2, dan $\beta$-FeSi2, sedangkan setelah oksidasi paduan terdiri dari fasa $\mathrm{Si}, \mathrm{FeSi}, \alpha-\mathrm{FeSi} 2, \beta-$ $\mathrm{FeSi} 2, \mathrm{Fe} 2 \mathrm{O} 3$ dan lapisan $\mathrm{SiO} 2$ bergantung pada komposisi masing-masing paduan logam. Setiap komposisi menunjukkan ketahanan oksidasi yang berbeda. Ketahanan oksidasi paduan logam $\mathrm{Fe}-\mathrm{Si}-\mathrm{Mg}$ cenderung meningkat dengan penambahan $\mathrm{Al}$ dengan nilai optimum adalah 2,2\%at.
\end{abstract}

Kata-kata kunci: paduan logam, Fe-Si-Mg-Al, metalurgi serbuk, oksidasi.

\begin{abstract}
Fe-Si-Mg-Al alloys with composition variation of ferrosilicon-magnesium and $\mathrm{Al}$ such as $100(\mathrm{Fe}-\mathrm{Si}$ $\mathrm{Mg}$ ), 97.79(Fe-Si-Mg)-2.21 Al, 94.79(Fe-Si-Mg)-5.27Al, and 89.16(Fe-Si-Mg)-10.84Al were prepared using a powder metallurgy techniques. The structure and oxidation resistance of the $\mathrm{Fe}-\mathrm{Si}-\mathrm{Mg}$-Al alloys with or without the $\mathrm{Al}$ addition were studied using X-ray Diffractometer (XRD) to determine the phases formed, Scanning Electron Microscope-Energy Dispersive X-ray Spectrometer (SEM-EDS) to determine morphology, element distribution and composition, and oxidation test was carried out in muffle furnace at $800^{\circ} \mathrm{C}$ for 8 cycles to determine the high temperature oxidation resistance of the $\mathrm{Fe}-\mathrm{Si}$ Mg-Al alloys. The results of XRD an SEM-EDS show that the Fe-Si-Mg alloys were successfully synthesized. The Fe-Si-Mg-Al alloy before oxidation consists of $\mathrm{Si}, \mathrm{FeSi}, \alpha-\mathrm{FeSi} 2$, dan $\beta$-FeSi2 phases, whereas after oxidation new phases of $\mathrm{Fe} 2 \mathrm{O} 3$ and $\mathrm{SiO} 2$ scale are formed. Each composition shows different oxidation resistance. The oxidation resistance of Fe-Si-Mg alloys increases with the optimum aluminum concentration which is about $2,2 \mathrm{at} \%$.
\end{abstract}


Keywords: alloys, Fe-Si-Mg-Al, powder metallurgy, oxidation.

\section{PENDAHULUAN}

Dalam bidang industri, bahan logam yang memiliki ketahanan pada suhu tinggi sangat dibutuhkan [1]. Pesatnya perkembangan teknologi khususnya di bidang pembangkit energi yang beroperasi pada suhu tinggi membutuhkan material yang kuat secara mekanik dan tahan akan degradasi lingkungan pada suhu tinggi [2], [3], [4]. Sifat ketahanan oksidasi adalah salah satu aspek yang paling penting untuk setiap bahan ketika digunakan untuk kondisi tersebut. Umumnya, suatu material atau paduan harus memiliki kemampuan untuk membentuk lapisan oksida pelindung pada permukaan terluar yang berfungsi sebagai pembatas terhadap lingkungan atmosfernya [5].

Bahan logam memiliki peran penting dan pengaruh yang signifikan terhadap efisiensi termal, produktivitas dan biaya operasional [6]. Beberapa faktor juga harus dipertimbangkan untuk memilih bahan yang tepat demi memperbaiki efisiensinya serta memperpanjang usia pemakaian dengan biaya minimum. Faktor-faktor tersebut termasuk sifat mekanik, ketahanan oksidasi temperatur tinggi, penggunaan atau fabrikasi komponen, dan ketersediaan material [7].

Logam dengan kadar kemurnian tinggi apabila dimanfaatkan sebagai bahan baku pembuatan material pembangkit, akan membutuhkan biaya yang cukup tinggi, sehingga diperlukan pengembangan bahan alternatif untuk menghasilkan material dengan performa yang sama atau lebih baik dengan bahan yang lebih ekonomis dan teknik yang lebih sederhana. Beberapa kriteria material yang diharapkan, untuk aplikasi komponen pembangkit diantaranya adalah material yang dikembangkan harus memiliki sifat mekanik yang baik dan tahan oksidasi pada temperatur tinggi. Banyak penelitian telah dilakukan untuk meningkatkan ketahanan oksidasi pada logam atau paduan, seperti penambahan alloying element atau pelapisan.

Dalam pengembangan paduan logam, pemilihan bahan dan pemilihan komposisi paduan menjadi suatu hal yang sangat penting. Bahan yang memiliki peranan penting untuk meningkatkan ketahanan oksidasi pada suhu tinggi salah satunya adalah Aluminium (Al) yang dapat berperan sebagai sumber pembentukan lapisan protektif $\mathrm{Al}_{2} \mathrm{O}_{3}$ [8]. Elemen $\mathrm{Fe}$ yang umumnya sebagai matriks dipadukan dengan elemen lain seperti Si [9], [10], [11] atau Mg [8], [11], [12], [13] dalam membentuk suatu paduan, dimana elemen Si dapat berperan meningkatkan kekerasan [8] dan juga untuk membentuk lapisan pelindung $\mathrm{SiO}_{2}$ [14], dan $\mathrm{Mg}$ dapat berperan untuk meningkatkan ketahanan korosi [15].

Untuk mensintesa paduan logam, penggabungan dua atau lebih unsur material yang berbeda dapat dilakukan dengan metode metalurgi serbuk, dimana bahan baku dikompaksi dan dapat disinter pada keadaan vakum atau inert atmosphere. Kelebihan teknik metalurgi serbuk ialah mudah diaplikasikan baik dalam skala laboratorium maupun industri [19].

Oleh karena itu, pada penelitian ini dilakukan sintesa paduan logam menggunakan bahan lump Ferrosilicon-magnesium dan Aluminium dengan teknik metalurgi serbuk dan sintering konvensional pada temperatur $1000^{\circ} \mathrm{C}$. Efek penambahan $\mathrm{Al}$ terhadap paduan logam $\mathrm{Fe}-\mathrm{Si}-\mathrm{Mg}$ dipelajari menggunakan XRD untuk mengidentifikasi fasa yang terbentuk, dan SEM-EDS untuk menganalisa struktur, sebaran dan komposisi elemen paduan, serta pengujian oksidasi dilakukan untuk mengetahui tingkat ketahanan oksidasinya paduan logam pada temperatur tinggi.

\section{METODOLOGI PENELITIAN}

Bahan yang digunakan dalam penelitian ini adalah lump Ferrosilicon-magnesium ( $\mathrm{Fe}-\mathrm{Si}-\mathrm{Mg}$ ) dengan komposisi seperti ditunjukkan pada Tabel 1. yang telah dihaluskan menggunakan shaker-mill dengan ukuran partikel $<74 \mu \mathrm{m}$ dan serbuk $\mathrm{Al}$ (MTIKorea, 99.9\%) dengan ukuran partikelnya $<30$ $\mu \mathrm{m}$.

TABEL 1. Komposisi lump Fe-Si-Mg

\begin{tabular}{|c|c|c|c|c|}
\hline Elemen & $\mathrm{Fe}$ & $\mathrm{Si}$ & $\mathrm{Mg}$ & Lainnya \\
\hline at $(\%)$ & 32,31 & 57,29 & 8,99 & 1,41 \\
\hline
\end{tabular}




\section{Preparasi Sampel dan Proses Pemaduan}

Preparasi pencampuran serbuk dilakukan dengan teknik mechanical alloying. Serbuk lump Fe-SiMg dan Al, ditimbang sesuai dengan komposisi seperti ditunjukkan pada TABEL 2. dan dicampur secara basah (wet mixing) dengan bola milling dan shaker-mill selama 2 jam dengan perbandingan massa serbuk dengan massa bola-bola milling yaitu 1:5.

TABEL 2. Variasi komposisi serbuk yang digunakan

\begin{tabular}{ccc}
\hline \multirow{2}{*}{$\begin{array}{c}\text { Kode } \\
\text { sampel }\end{array}$} & \multicolumn{2}{c}{ Rasio (\%at) } \\
\cline { 2 - 3 } A & Fe-Si-Mg & Al \\
B & $100 \%$ & $0 \%$ \\
C & $97,79 \%$ & $2,21 \%$ \\
D & $94,73 \%$ & $5,27 \%$ \\
\hline
\end{tabular}

Serbuk yang telah dipadukan selanjutnya dikeringkan pada suhu kamar dengan diletakkan pada cawan petri dan ditutup dengan Alumunium-foil yang telah dilubangi. Setelah proses pengeringan selesai, serbuk Fe-Si-Mg-Al ditimbang sebanyak 1,25 gram, kemudian dicetak menggunakan alat kompaksi dengan tekanan 8 ton, waktu penahanan selama 3 menit, dan kemudian sampel dikeluarkan dari cetakan. Selanjutnya hasil kompaksi (green-compact) diletakan dengan cawan keramik dan diberikan perlakukan panas atau sintering di dalam tungku tubular pada temperatur $1000{ }^{\circ} \mathrm{C}$ pada kondisi vakum bertekanan $5.10^{-1} \mathrm{mBar} /$ Tor, dengan heating-rate $5{ }^{\circ} \mathrm{C} / \mathrm{menit}$, waktu penahanan $2 \mathrm{jam}$, dan cooling-rate secara alami.

Uji oksidasi dilakukan melalui proses pemanasan pada suhu $800^{\circ} \mathrm{C}$ selama 8 siklus, dimana setiap siklus terdiri dari 20 jam pemanasan di dalam tungku muffle dan 4 jam pendinginan di udara ruang. Setelah proses pendinginan, paduan $\mathrm{Fe}-\mathrm{Si}-\mathrm{Mg}$-Al ditimbang perubahan massanya dengan cara mengukur selisih massa setelah pengujian pada setiap siklus dikurangi dengan massa paduan awal dibagi dengan luas permukaan paduan mula-mula.

\section{Karakterisasi Sampel}

XRD tipe Rigaku Smartlab (radiasi $\mathrm{Cu}-\mathrm{K} \alpha$ dan $\lambda=1,541862 \AA$ ) digunakan untuk mengkarakterisasi fasa yang terbentuk pada paduan Fe-Si-Mg-Al. Sebelum analisa morfologi paduan secara cross-section pada paduan sebelum dan sesudah oksidasi, paduan $\mathrm{Fe}-\mathrm{Si}-\mathrm{Mg}-\mathrm{Al}$ di-mounting dengan resin, dipotong, dan diamplas menggunakan kertas $\mathrm{SiC}$ sampai grit 5000, dan dipoles akhir menggunakan kain DP-Nap. Analisa morfologi cross-section, pesebaran elemen dan analisa komposisi tiap paduan Fe-Si-Mg-Al dilakukan dengan menggunakan SEM-EDS (SEM Hitachi SU3500-EDX Horiba). Hal ini dilakukan untuk mengetahui apakah pesebaran elemen pada paduan homogen dan untuk mengidentifikasi terbentuknya lapisan pelindung pada paduan setelah oksidasi.

\section{HASIL DAN PEMBAHASAN}

Sintesa paduan logam Fe-Si-Mg-Al telah berhasil dilakukan dengan teknik metalurgi serbuk dan dapat ditunjukkan pada Gambar 1(a) dan 1(b). Proses sintesa serbuk menggunakan shaker-mill selama 2 jam. Gambar 1(a) menunjukkan bahan awal serbuk Al sebelum pemaduan, 1(b) serbuk FeSi-Mg dari bahan lump setelah proses penghalusan dengan shaker-mill selama 2 jam, 1(c) serbuk hasil pemaduan serbuk Fe-Si-Mg dan Al dengan shaker-mill selama 2 jam. Pada GAMBAR 1(d) dapat dilihat bahwa green-compact paduan Fe-Si-Mg-Al, telah disintesa dengan baik. 


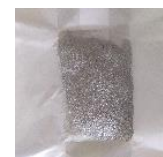

(a)

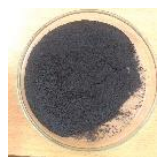

(b)

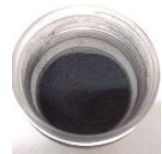

(c)

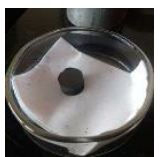

(d)

GAMBAR 1. Bahan (a) serbuk Al, (b) serbuk lump Fe-Si-Mg, (c) campuran serbuk Fe-Si-Mg-Al, dan (d) paduan greencompact $\mathrm{Fe}-\mathrm{Si}-\mathrm{Mg}-\mathrm{Al}$.

\section{Hasil karakterisasi XRD sebelum uji oksidasi}

GAMBAR 2 menunjukkan pola difraksi XRD pada paduan logam Fe-Si-Mg-Al dengan variasi komposisi berbeda yang terdiri dari sampel [A] 100(Fe-Si-Mg), [B] 97,79(Fe-Si-Mg)-2,21Al, [C] 94,79(Fe-Si-Mg)-5,27Al, dan [D] 89,16(Fe-Si-Mg)-10,84Al.

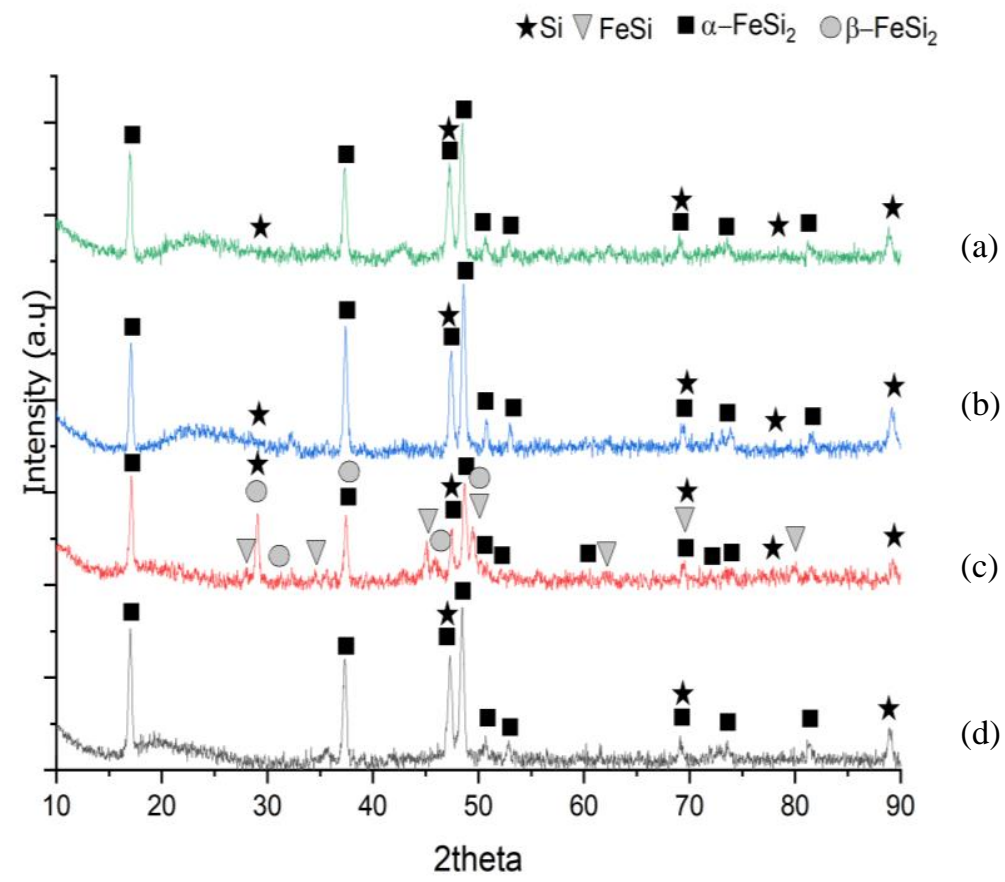

GAMBAR 2. Pola difraksi XRD paduan Fe-Si-Mg-Al sebelum uji oksidasi: (a) Paduan [A], (b) paduan [B], (c) paduan [C], dan (d) paduan [D].

Berdasarkan gambar di atas dapat dilihat bahwa fasa yang terdeteksi bergantung pada komposisi masing-masing paduan. Fasa $\mathrm{FeSi}_{2}$ yang terdeteksi memiliki struktur kristal tertragonal $\alpha-\mathrm{FeSi}_{2}$ dan/atau orthorhombic $\beta-\mathrm{FeSi}_{2}$ [16], [17]. Dari hasil di atas, paduan logam A, B, C dan D tanpa atau dengan penambahan $\mathrm{Al}$ tersusun atas $\alpha-\mathrm{FeSi}_{2}$ dan $\mathrm{Si}$, namun pada paduan logam $\mathrm{C}$ terdeteksi fasa lain yaitu $\mathrm{FeSi}$ dan $\beta-\mathrm{FeSi}_{2}$. Hal ini dimungkinkan dipengaruhi oleh solubility limit $\mathrm{Al}$ di dalam $\mathrm{Fe}-$ Si-Mg. Sehingga terdeteksi fasa baru pada paduan logam 94,79(Fe-Si-Mg) dengan penambahan 5,27 $\%$ at $\mathrm{Al}$.

\section{Hasil Uji Ketahanan Oksidasi pada Temperatur $800^{\circ} \mathrm{C}$}

GAMBAR 3 menunjukkan kurva hasil uji ketahanan oksidasi paduan logam Fe-Si-Mg-Al pada temperatur $800^{\circ} \mathrm{C}$ selama 8 siklus. 


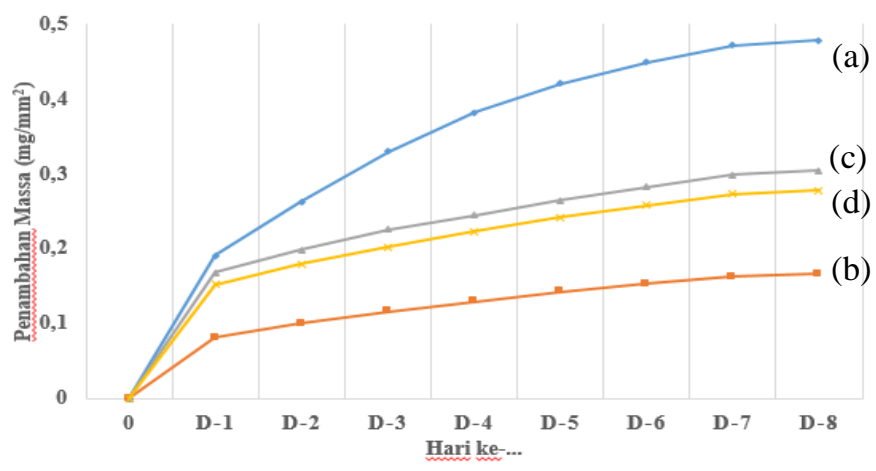

GAMBAR 3. Grafik penambahan massa persatuan luas permukaan sampel paduan Fe-Si-Mg-Al: (a) Paduan [A], (b) Paduan [B], (c) Paduan [C], dan (d) Paduan [D] setelah perlakuan uji oksidasi pada suhu $800^{\circ} \mathrm{C}$ selama 8 siklus

Berdasarkan gambar di atas dapat dilihat bahwa terjadi penambahan massa pada setiap siklusnya. Paduan [A] memiliki penambahan massa paling tinggi diantara paduan logam yang lainnya. Hal ini menunjukkan bahwa Paduan $[\mathrm{A}]$ memiliki ketahanan oksidasi yang paling rendah dibandingkan dengan paduan logam [B], [C] dan [D]. Penambahan Al dapat meningkatkan ketahanan oksidasi paduan logam $\mathrm{Fe}-\mathrm{Si}-\mathrm{Mg}$ bergantung pada konsentrasi masing-masing paduan. Pertambahan massa persatuan luas yang paling kecil terjadi pada paduan logam $[\mathrm{B}]$ yang mengindikasikan bahwa paduan tersebut memiliki ketahanan oksidasi yang paling baik dengan konsentrasi elemen Al sebanyak $2,21 \%$ at.

\section{Hasil karakterisasi XRD setelah uji oksidasi}

GAMBAR 4 menunjukkan pola XRD pada paduan logam Fe-Si-Mg-Al dengan variasi komposisi berbeda setelah dioksidasi pada temperatur $800^{\circ} \mathrm{C}$ selama 8 siklus.

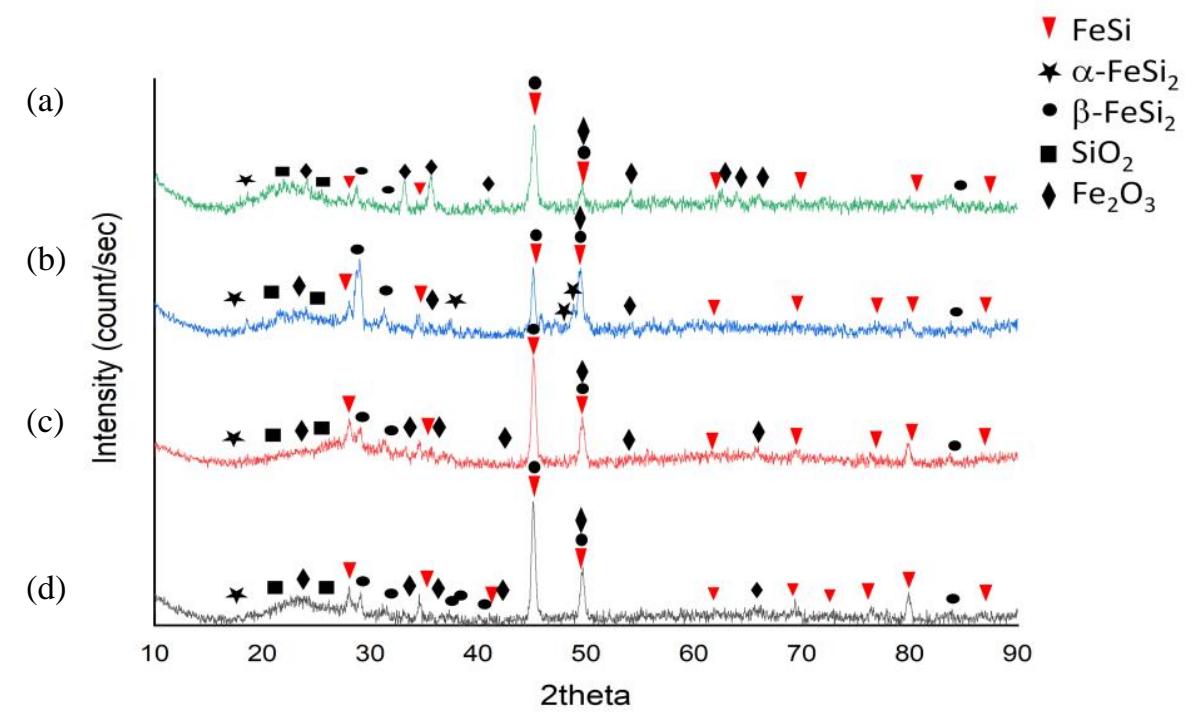

GAMBAR 4. Pola XRD paduan Fe-Si-Mg-Al: (a) Paduan [A], (b) Paduan [B], (c) Paduan [C], dan (d) Paduan [D] sebelum dan setelah perlakuan uji oksidasi pada temperatur $800^{\circ} \mathrm{C}$ selama 8 siklus.

Hasil analisa menunjukkan bahwa paduan $\mathrm{Fe}-\mathrm{Si}-\mathrm{Mg}$ tanpa atau dengan penambahan $\mathrm{Al}$ tersusun atas fase $\mathrm{FeSi}, \alpha-\mathrm{FeSi}_{2}, \beta-\mathrm{FeSi}_{2}, \mathrm{SiO}_{2}$ dan $\mathrm{Fe}_{2} \mathrm{O}_{3}$. Seperti hasil analisa XRD pada paduan $\mathrm{Fe}-\mathrm{Si}-\mathrm{Mg}$ Al sebelum uji oksidasi, diidentifikasi bahwa fasa $\mathrm{FeSi}, \alpha-\mathrm{FeSi}{ }_{2}$, dan $\beta-\mathrm{FeSi}_{2}$ masih terdeteksi dalam paduan tersebut. Fasa baru yang terbentuk setelah oksidasi yaitu fasa $\mathrm{Fe}_{2} \mathrm{O}_{3}$ dan crystalline-SiO${ }_{2}$. Disamping itu, adanya peningkatan background noise pada kisaran sudut $2 \theta \pm 17^{\circ}$ sampai dengan $\pm 27^{\circ}$ juga mengindikasikan adanya terbentuk $\mathrm{SiO}_{2}$ dengan struktur amorf. $\mathrm{SiO}_{2}$ yang terbentuk pada 
lapisan terluar dapat berperan sebagai lapisan pelindung dari paduan [1], [5] ketika terpapar Oksigen pada temperatur tinggi dan mencegah difusi Oksigen ke dalam paduan . Menarik untuk didiskusikan, jika dibandingkan dengan hasil XRD sebelum oksidasi fasa $\alpha-\mathrm{FeSi}_{2}$ yang terbentuk lebih sedikit. Perubahan ini dimungkinkan disebabkan oleh reaksi oksidasi $\alpha-\mathrm{FeSi}_{2}$ dengan oksigen membentuk oksida Fe dan Si, seperti yang terdeteksi pada hasil analisa XRD di atas.

\section{Hasil karakterisasi SEM-EDS setelah uji oksidasi}

GAMBAR 5 menunjukkan gambar penampang lintang paduan logam [A] dan [B] setelah diuji oksidasi pada suhu $800^{\circ} \mathrm{C}$ yang diperoleh melalui karakterisasi SEM-EDS.

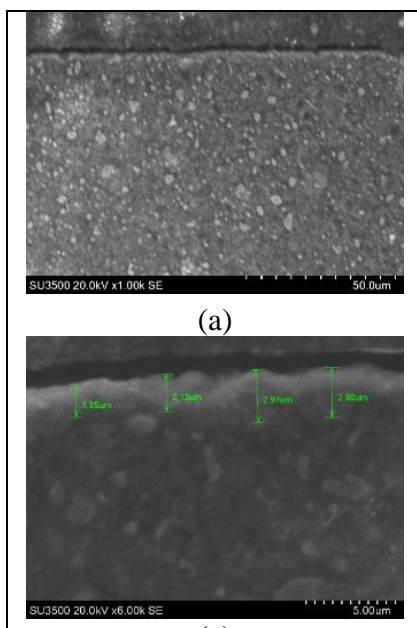

(c)

[A] 100(Fe-Si-Mg)

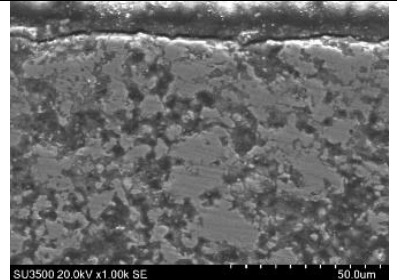

(b)

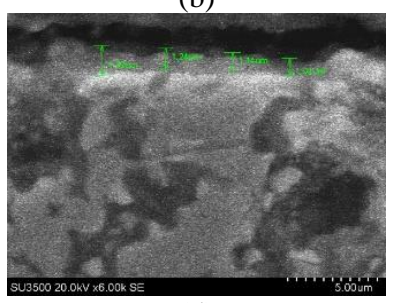

(d)

[B] $97.79(\mathrm{Fe}-\mathrm{Si}-\mathrm{Mg})-2.21 \mathrm{Al}$

GAMBAR 5. Morfologi SEM paduan logam Fe-Si-Mg-Al: (a, c) paduan [A] dan (b, d) paduan [B] setelah uji ketahanan oksidasi pada temperatur $800^{\circ} \mathrm{C}$ selama 8 siklus.

Hasil di atas menunjukkan bahwa penambahan $\mathrm{Al}$ mempengaruhi struktur paduan $\mathrm{Fe}-\mathrm{Si}-\mathrm{Mg}$. GAMBAR 5(a,b) menunjukkan bahwa masing-masing paduan logam [A] dan [B] terdapat daerah berwarna gelap yang umumnya merupakan pori atau oksida. Paduan [A] memilik pori yang lebih kecil namun tersebar merata, sedangkan paduan [B] memiliki pori yang lebih sedikit, namun berukuran lebih besar dibandingkan dengan paduan [A]. Berdasarkan hasil analisa penampang lintang nampak bahwa ketebalan lapisan oksida yang terbentuk pada lapisan terluar setelah uji oksidasi bervariasi. Paduan logam [A] tanpa penambahan elemen Al, memiliki lapisan oksida dengan ketebatan antara 1,85 - 2,97 $\mu \mathrm{m}$, sedangkan paduan [B] memiliki ketebalan lapisan bervariasi dari $1,01-1,32 \mu \mathrm{m}$. Hal ini menunjukkan bahwa dengan penambahan elemen Al hingga 2,21 wt $\%$, paduan Fe-Si-Mg-Al memiliki lapisan oksida yang lebih tipis dan pertambahan massa persatuan luas permukaan yang paling kecil (GAMBAR 3). Sehingga, dapat disimpulkan bahwa lapisan yang terbentuk dapat berperan sebagai lapisan pelindung terhadap difusi oksigen ke dalam permukaan sampel.

Pada studi ini juga dilakukan analisa komposisi dengan SEM-EDS pada paduan logam [A] 100(Fe-Si-Mg] dan [B] 97.79(Fe-Si-Mg)-2.21Al dengan hasil masing-masing seperti ditunjukkan pada Tabel 3 dan 4. Berdasarkan gambar BSE-SEM, paduan logam [A] tersusun dari 3 warna yang berbeda, yaitu abu-abu (1), abu-abu keputihan (2), dan abu-abu kehitaman (3). Hasil analisa elemen pada titik (1), (2), dan (3) menunjukkan bahwa lokasi tersebut terdiri dari elemen-elemen $\mathrm{Fe}, \mathrm{Si}, \mathrm{Al}$, $\mathrm{Mg}$, dan $\mathrm{O}$ dengan konsentrasi yang berbeda. 
TABEL 3. Analisa point SEM-EDS paduan logam [A] 100(Fe-Si-Mg)

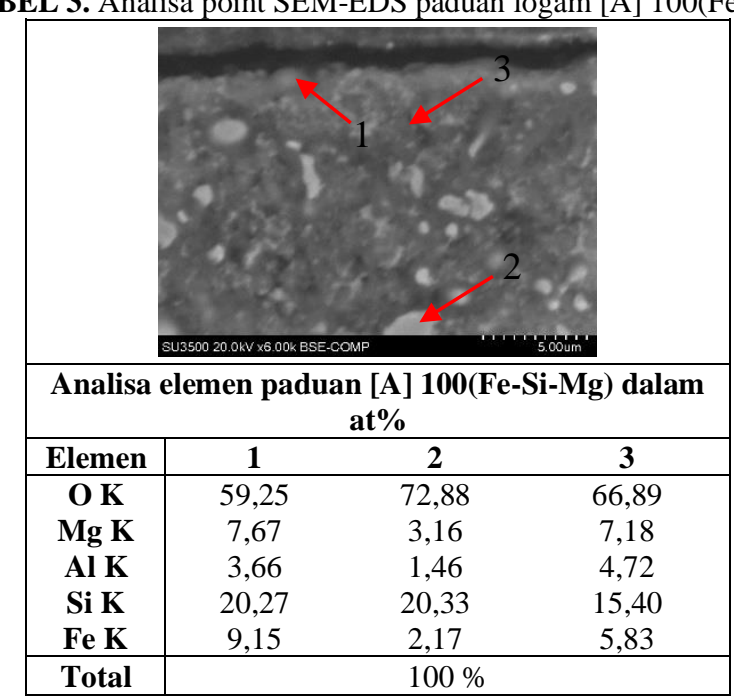

Pada paduan logam [B], morfologi permukaan dapat dibedakan menjadi 3 daerah dengan kontras warna yang berbeda yaitu, abu-abu kehitaman (1), abu-abu muda (2), dan abu-abu keputihan (3). Hasil analisa elemen pada daerah abu-abu kehitaman (1) terdiri dari elemen-elemen secara berurutan $\mathrm{Fe}, \mathrm{Si}, \mathrm{Al}, \mathrm{O}(9,45 \%, 32,21 \%, 6,86 \%, 51,48 \%)$, demikian juga pada daerah ke (2) secara berturutturut $\mathrm{Fe}, \mathrm{Si}, \mathrm{O}(27,84 \%, 58,92 \%, 13,24 \%)$ yang fase utamanya adalah fasa $\mathrm{FeSi}_{2}$ dan $\mathrm{SiO}_{2}$. Sedangkan, pada daerah ke (3), elemen-elemen secara berurutan Fe dan Si (31,62\% dan 68,38\%) yang merupakan fasa $\mathrm{FeSi}_{2}$. Hasil ini sesuai dengan hasil analisa fasa XRD seperti yang telah disebutkan sebelumnya.

TABEL 4. Analisa point SEM-EDS paduan logam [B] 97.79(Fe-Si-Mg)-2.21Al dalam at\%

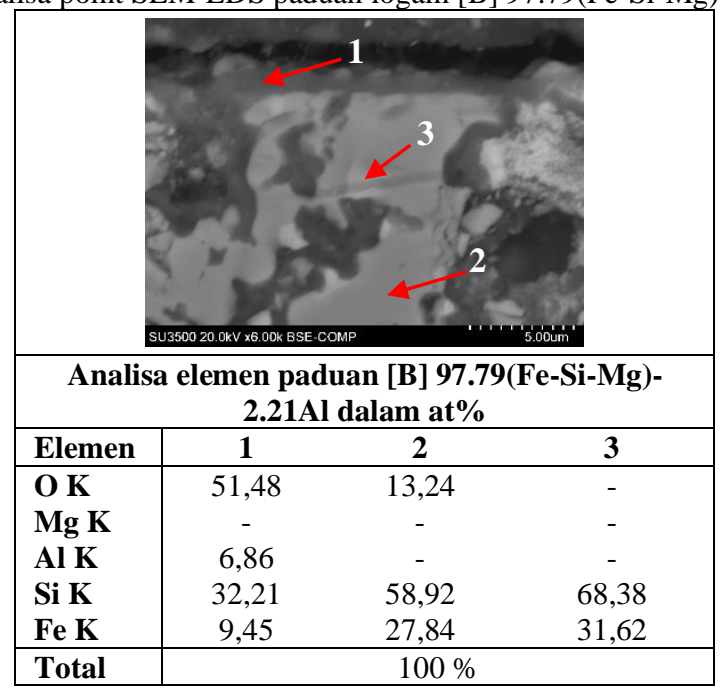

Sebaran elemen-elemen pada penampang lintang paduan logam Fe-Si-Mg-Al setelah uji oksidasi ditunjukkan pada GAMBAR 6. Elemen O terlihat jelas tersebar merata terutama pada paduan logam A pada area yang diobservasi. Hal ini menunjukkan bahwa oksidasi internal telah terjadi pada bagian dalam paduan logam tersebut. Oksigen dapat berdifusi dengan mudah ke dalam paduan logam melalui pori atau retak yang terdapat pada paduan logam tersebut. Karena elemen Si memiliki sifat afinitas yang tinggi terhadap oksigen, Si dapat mengikat oksigen dengan mudah yang berdifusi melalui pori atau retak, yang berdampak pada terjadinya oksidasi internal. Difusi atau bereaksinya $\mathrm{Si}$ dengan oksigen, meninggalkan tempat mulanya yang menyebabkan terbentuknya vacancy atau pori baru pada paduan logam tersebut. 

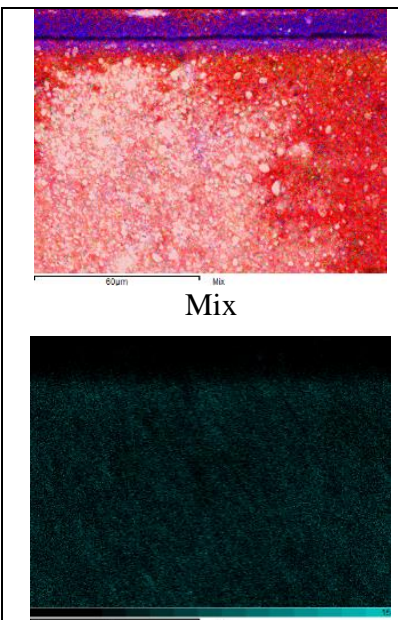

$\mathrm{Si}$

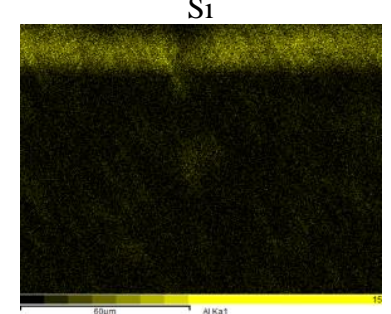

$\mathrm{Al}$

(a)

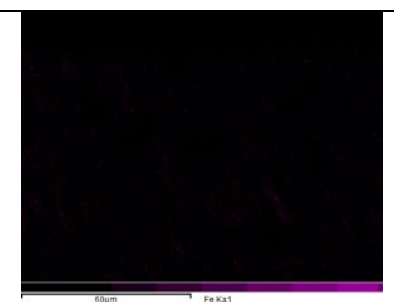

$\mathrm{Fe}$

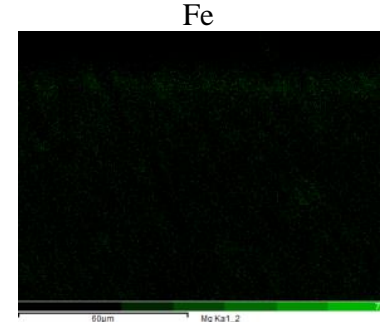

$\mathrm{Mg}$

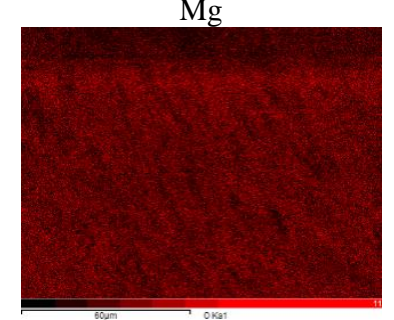

O

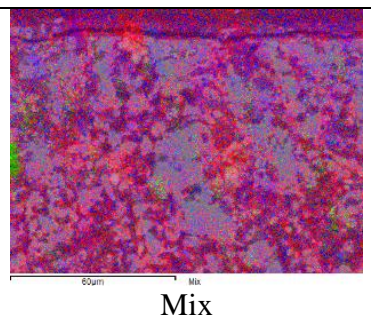

Mix

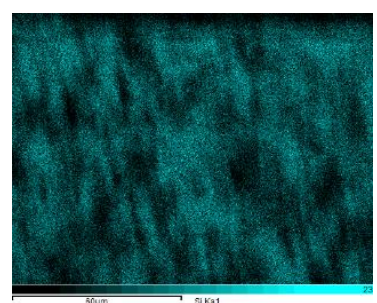

$\mathrm{Si}$

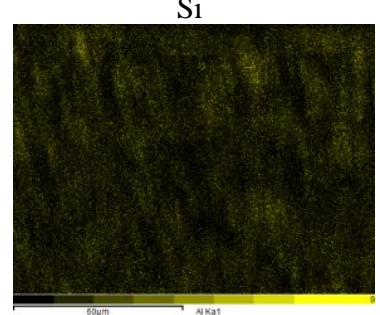

$\mathrm{Al}$

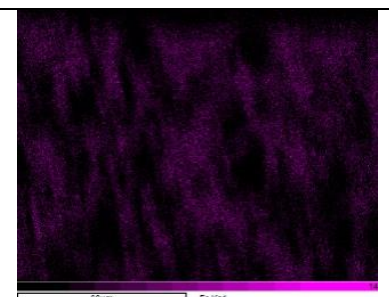

$\mathrm{Fe}$

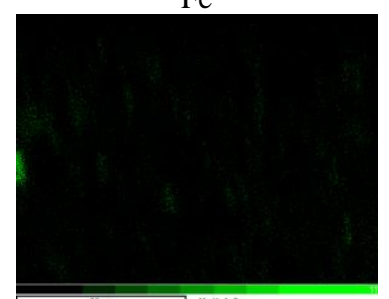

$\mathrm{Mg}$

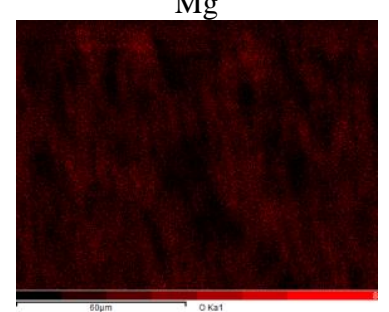

$\mathrm{O}$

(b)

GAMBAR 6. Analisa Mapping EDS pada paduan logam Fe-Si-Mg-Al dengan variasi komposisi: (a) [A] $100(\mathrm{Fe}-\mathrm{Si}-\mathrm{Mg})$ dan (b) [B] 97.79(Fe-Si-Mg)-2.21 Al (dalam at\%) setelah uji ketahanan oksidasi pada temperature $800^{\circ} \mathrm{C}$ selama 8 siklus.

\section{KESIMPULAN}

Sintesa paduan Fe-Si-Mg-Al dengan teknik metalurgi serbuk telah berhasil dilakukan. Berdasarkan hasil yang didapat, paduan $\mathrm{Fe}-\mathrm{Si}-\mathrm{Mg}$-Al pada saat sebelum oksidasi tersusun atas fasa $\mathrm{Si}, \mathrm{FeSi}, \alpha-\mathrm{FeSi}_{2}$, dan/atau $\beta-\mathrm{FeSi}_{2}$ bergantung pada komposisi paduannya. Hasil analisa mikrostruktur juga menunjukkan bahwa penambahan Al mempengaruhi struktur morfologi paduan, sejumlah pori dan oksida terbentuk pada permukaan sampel Fe-Si-Mg. Ketahanan oksidasi paduan Fe-Si-Mg meningkat dengan penambahan $\mathrm{Al}$, dengan ketahanan oksidasi paling optimal dicapai melalui penambahan 2,21 \%at Al. Berdasarkan hasil analisa XRD diketahui bahwa setelah oksidasi, paduan logam Fe-Si-Mg-Al membentuk fasa $\mathrm{SiO}_{2}$ dan $\mathrm{Fe}_{2} \mathrm{O}_{3}$. Disamping itu, uji oksidasi juga mempengaruhi perubahan struktur kristal fasa $\mathrm{FeSi}_{2}$ dari tetragonal menjadi orthorhombic.

\section{UCAPAN TERIMAKASIH}

Kegiatan penelitian ini dibiayai dari "Kegiatan Tematik P2 Fisika-LIPI 2018". Ucapan terima kasih, penulis sampaikan kepada Pusat Penelitian Fisika-LIPI yang telah memfasilitasi sarana dan prasarana dalam pelaksanaan penelitian ini.

\section{REFERENSI}

[1] K. Kurokawa et al., "High-temperature corrosion resistance of $\mathrm{SiO} 2$-forming materials," Corrosion Reviews, vol. 36, no. 1, pp. 65-74, Feb 2018, doi: 10.1515/corrrev-2017-0069.

[2] G. W. Meetham dan M. H. Van de Voorde, "Requirements of High Temperature Materials," dalam Materials for High Temperature Engineering Applications, Berlin, Heidelberg: Springer Berlin Heidelberg, pp. 19-34, 2000. 
[3] T. Gao et al., "Evolution of Fe-rich phases in Mg melt and a novel method for separating Al and Fe from Al-Si-Fe alloys," Materials \& Design, vol. 134, pp. 71-80, Nov 2017, doi: 10.1016/j.matdes.2017.08.029.

[4] W. Gao, "Investigation of hollow bimetal oxide nanomaterial and their catalytic activity for selective oxidation of alcohol," Molecular Catalysis, vol. 448, pp. 63-70, Apr 2018, doi: 10.1016/j.mcat.2018.01.028.

[5] T. Sudiro et al., "A Comparative Study of High Temperature Corrosion of Al2O3, SiO2 and Al2O3-SiO2 Forming Alloys in a Na2SO4-NaCl Atmosphere," Oxid Met, vol. 80, no. 5-6, pp. 589-597, Des 2013, doi: 10.1007/s11085-013-93 98-7.

[6] G. Gustafsson, T. Thorvaldsson dan G. L. Dunlop, "The influence of Fe and $\mathrm{Cr}$ on the microstructure of cast Al-Si-Mg alloys," MTA, vol. 17, no. 1, pp. 45-52, Jan 1986, doi: 10.1007/BF02644441.

[7] Kelly et al., "Material Selection Consideration for Thermal Process Equipment." U.S. Departement of Energy, 2004.

[8] H. Tanihata et al., "Effect of casting and homogenizing treatment conditions on the formation of $\mathrm{Al}-\mathrm{Fe}-\mathrm{Si}$ intermetallic compounds in $6063 \mathrm{Al}-\mathrm{Mg}-\mathrm{Si}$ alloys," p. 2.

[9] K. Kinoshita, K. Yamada dan H. Matsutera, "Reactive Ion Etching of Fe-Si-A1 Alloy for Thin Film Head," p. 3.

[10] S. Yoshida et al., "Permeability and electromagnetic-interference characteristics of $\mathrm{Fe}-\mathrm{Si}$ Al alloy flakes-polymer composite," Journal of Applied Physics, vol. 85, no. 8, pp. 46364638, Apr 1999, doi: 10.1063/1.370432.

[11] S. J. Andersen et al., "The crystal structure of the B0 phase in Al-Mg-Si alloys," p. 16.

[12] G. A. Edwards et al., "The precipitation sequence in Al-Mg-Si alloys," Acta Materialia, vol. 46, no. 11, pp. 3893-3904, Jul 1998, doi: 10.1016/S1359-6454(98)00059-7.

[13] Y. L. Liu, S. B. Kang, dan H. W. Kim, "The complex microstructures in an as-cast Al-MgSi alloy," Materials Letters, vol. 41, no. 6, hlm. 267-272, Des 1999, doi: 10.1016/S0167577X(99)00141-X.

[14] K. S. Park dan Y. Kim, "Processing of SiO2 Protective Layer Using HMDS Precursor by Combustion CVD," J. Nanosci. Nanotech, vol. 11, no. 8, pp. 7265-7268, Agu 2011, doi: 10.1166/jnn.2011.4818.

[15] I. O. Wilson, "Magnesium oxide as a high-temperature insulant," IEE Proc. A Phys. Sci. Meas. Instrum, Manage. Educ. Rev. UK, vol. 128, no. 3, p. 159, 1981, doi: 10.1049/ip-a1.1981 .0026$.

[16] S. Kumar dan K. A. Q. O'Reilly, "Influence of $\mathrm{Al}$ grain structure on $\mathrm{Fe}$ bearing intermetallics during DC casting of an Al-Mg-Si alloy," Materials Characterization, vol. 120, pp. 311-322, Okt 2016, doi: 10.1016/j.matchar.2016.09.017.

[17] C. Kloc et al., "Preparation and properties of FeSi, a-FeSi2 and b-FeSi2 single crystals," p. 4.

[18] A. M. Nymark, "Oxidation of silicon powder in humid air," p. 122, Jun 2012.

[19] M. H. Van de Voorde \& W. Betteridge, "High-temperature materials and industrial applications," EUR 8841 1983, Euro. Abstr. Sect. I, vol. 22, no. 3, p. 22, 1991. 
